\title{
In situ measurements of volatile organic compounds in a boreal forest
}

\author{
H. Hakola ${ }^{1}$, H. Hellén ${ }^{1}$, M. Hemmilä ${ }^{1}$, J. Rinne ${ }^{2}$, and M. Kulmala ${ }^{2}$ \\ ${ }^{1}$ Finnish Meteorological Institute, P.O.Box 503, 00101 Helsinki, Finland \\ ${ }^{2}$ Department of Physical Sciences, University of Helsinki, P.O. Box 68, 00014 University of Helsinki, Finland
}

Correspondence to: H. Hakola (hannele.hakola@fmi.fi)

Received: 2 May 2012 - Published in Atmos. Chem. Phys. Discuss.: 19 June 2012

Revised: 5 October 2012 - Accepted: 21 October 2012 - Published: 6 December 2012

\begin{abstract}
We present biogenic VOC, including sesquiterpenes, measurements at the SMEAR II station (Station For Measuring Forest Ecosystem-Atmosphere Relations) in Finland using an in situ gas chromatograph mass-spectrometer with $2 \mathrm{~h}$ time resolution. The measurements were conducted over the period October 2010-October 2011, at least one week every month. To our knowledge there are no earlier species-speciated semi-continuous BVOC data also covering dormant periods. This was also the first time sesquiterpene mixing ratios were measured in a boreal forest.

During the winter months, and still in March, the mixing ratios of all biogenic compounds were very low, most of the time below detection limits. The monoterpene mixing ratios increased in April and started to show diurnal variability, with maximum mixing ratio at night and minima during the day. The diurnal variability continued until October, after which the mixing ratios decreased and then only occasional episodes took place. The diurnal variation was affected by boundary layer height. Sesquiterpene mixing ratios were very low, only a few ppt. The main sesquiterpenes were longifolene and isolongifolene. The diurnal variation of isoprene was opposite to the mono- and sesquiterpene diurnal curve due to isoprene's light dependent emissions. Due to its daytime maximum mixing ratios, isoprene also dominated hydroxyl radical reactivity in summer even though our isoprene measurements are underestimates due to a breakthrough in a cold trap.
\end{abstract}

\section{Introduction}

Volatile organic compounds (VOCs), especially isoprene and monoterpenes, but also some sesquiterpenes, are emitted in large amounts from a boreal forest (Tarvainen et al., 2007; Rinne et al., 2009). In the atmosphere they react rapidly with the hydroxyl radical, the nitrate radical and ozone, thus, participating in the complex atmospheric chemical processes forming ozone (Sillman, 1999; Kleinmann, 2005). They are also involved in new particle formation and growth processes (Kulmala et al., 2004a; Tunved et al., 2006; Bonn et al., 2008). Both ozone formation and new particle formation and growth have significant climate effects and, thus, both processes should be quantified. This needs information on the mixing ratios of individual VOCs in air throughout the four seasons. Previously, the mixing ratios of biogenic VOCs have been measured in western Eurasian boreal forests using pumped sampling into the sample canisters (Laurila and Hakola, 1996; Hakola et al., 2006a), adsorbent tubes (Hakola et al., 2003, 2009), and by online proton transfer reaction - mass spectrometry, PTR-MS (Rinne et al., 2005; Lappalainen et al., 2009). Often the measurements conducted by the two first-mentioned techniques, requiring laboratory analysis by gas chromatographic techniques, enable good compound identification, but they lack the time resolution of the last-mentioned technique (PTR-MS). However, compound identification in PTR-MS measurements is less certain than with GC-MS, and PTR-MS cannot separate compounds with the same mass, e.g., monoterpenes, from each other.

As an example of earlier research, the solid adsorbent sampling measurements by Hakola et al. (2009) at a boreal forest site, SMEAR II, cover a uniquely long time-period, seven 
years, but samples were only taken at midday about twice a week. However, they reveal significant variations in annual patterns of mixing ratios, which are influenced by biological and meteorological factors. The measurements at the same site by PTR-MS (Rinne et al., 2005) show the contrasting diurnal cycles of e.g., isoprene and monoterpenes, but cannot separate the individual monoterpenes.

There is, thus, a need for well-identified VOC mixing ratio data, especially speciated monoterpene mixing ratio data, covering full annual cycles with a time resolution capable of revealing diurnal cycles. There is no earlier data about sesquiterpene diurnal variability in boreal areas. The mixing ratio data is needed especially for model validation purposes.

We have measured biogenic VOC mixing ratios, including sesquiterpenes, at the SMEAR II station (Station For Measuring Forest Ecosystem-Atmosphere Relations) in Finland using an in situ gas chromatograph mass-spectrometer. With this technique we are able to obtain a 60-min-long measurement of well-identified mixing ratios of VOCs every $120 \mathrm{~min}$. Our focus was on mono-and sesquiterpene mixing ratios. The measurements were conducted over the period October 2010-October 2011, for at least one week every month.

Williams et al. (2007) have stressed the importance of also measuring different mirror images (enatiomers) of monoterpenes separately. Different enantiomers can have been formed by different mechanisms, i.e., in a light- or temperature-dependent way. Plants can use different enantiomers for different purposes, e.g., for defense against insects or for attracting pollinators. By studying the enantiomeric signatures of mono- and sesquiterpenes, it is possible to get more information on the processes that are controlling their emissions. Yassaa et al. (2001, 2005, 2007) have studied the enantiomeric compositions of the emissions of different plants, but here we have studied the enantiomeric composition in ambient air samples.

\section{Methods}

\subsection{Measurement site}

The measurements were conducted at the SMEAR II station (Station For Measuring Forest Ecosystem-Atmosphere Relations $61^{\circ} 51^{\prime} \mathrm{N}, 24^{\circ} 18^{\prime} \mathrm{E}, 181 \mathrm{~m}$ a.s.1.) at Hyytiälä, in southern Finland (Hari and Kulmala, 2005). The largest nearby city is Tampere with 200000 inhabitants. It is located $60 \mathrm{~km}$ to the south-west of the site. The nearest vegetation is a homogeneous Scots pine forest with some birches and Norway spruces growing nearby. The instrument was located in a container about 4 metres outside the forest in a small opening. The VOC inlet was on the roof of a container at about $2.5 \mathrm{~m}$.

\subsection{VOC measurements}

The VOCs were measured using an on-line gaschromatograph-mass-spectrometer. Ambient air was drawn through a 3 or $5 \mathrm{~m}$ long stainless steel tube (od $1 / 4$ inch) at a flow rate of $11 \mathrm{~min}^{-1}$. According to the instructions given by Helmig et al. (2003) the tubes were heated to $120^{\circ} \mathrm{C}$ to avoid any losses of sesquiterpenes. The recoveries were at least $89 \%$ for the compounds found in the present study. The heated inlet also destroyed ozone and no other ozone removal was needed (Hellén et al., 2012). The ozone removal by a heated inlet and subsequent VOC recoveries has been tested by Hellén et al. (2012). VOCs in a $38 \mathrm{ml} \mathrm{min}^{-1}$ subsample were collected in the cold trap of a thermal desorption unit (Perkin Elmer ATD-400) packed with Tenax TA. The trap was kept at $10^{\circ} \mathrm{C}$ (after June 2011 at $20^{\circ} \mathrm{C}$ ) to prevent water vapour present in the air from accumulating into the trap. This allowed the analysis of monoand sesquiterpenes, but not isoprene, since it needs lower temperatures or stronger adsorbents. Approximately $60 \%$ of the isoprene was lost during collection. Also benzene was not retained totally in the cold trap at $20^{\circ} \mathrm{C}$, and about $60 \%$ of the benzene was lost. At $10^{\circ} \mathrm{C}$ there was no breakthrough of benzene and, thus, benzene results are reliable until June. Sesquiterpene measurements were unreliable in June and in July due to the bad quality of the chromatography at the end of the chromatogramme, and these data were not used. The thermal desorption instrument was connected to a gas chromatograph (HP 5890) with DB-1 column $(60 \mathrm{~m}$, i.d. $0.25 \mathrm{~mm}$, f.t. $0.25 \mu \mathrm{m}$ ) and a mass selective detector (HP 5972). One 60-min sample was collected every other hour. The system was calibrated using liquid standards injected on Tenax TA-Carbopack B adsorbent tubes and analysed using the offline mode of the instrument. The detection limit was below 1 ppt for all of the analytes, much lower than in the corresponding off-line analysis. The precision of the analysis (standard deviation of repeated calibration samples) was about $8-10 \%$ for most of the mono-and sesquiterpenes, p-cymene and linalool had higher deviations $14 \%$ and $22 \%$, respectively. The precision of the analysis of aromatic hydrocarbons was 6-12\%. Only benzene had higher standard deviation, $16 \%$.

The measurements did not cover the whole year, but at least one week was measured each month. The weeks for measurements were selected randomly. In June and in July sesquiterpene data was lost due to chromatographic problems.

Samples were also taken for the enantiomeric determination of $\alpha$-pinene, camphene and limonene. These compounds were chosen, because they were the only ones available. Pumped samples were taken each month during the growing season and analysed later in the laboratory using a thermal desorpter (Markes Unity) with a gas chromatograph (Agilent 7890A) and a mass spectrometer (Agilent 5973N) with an enantiomeric column (Cyclodex-B). 


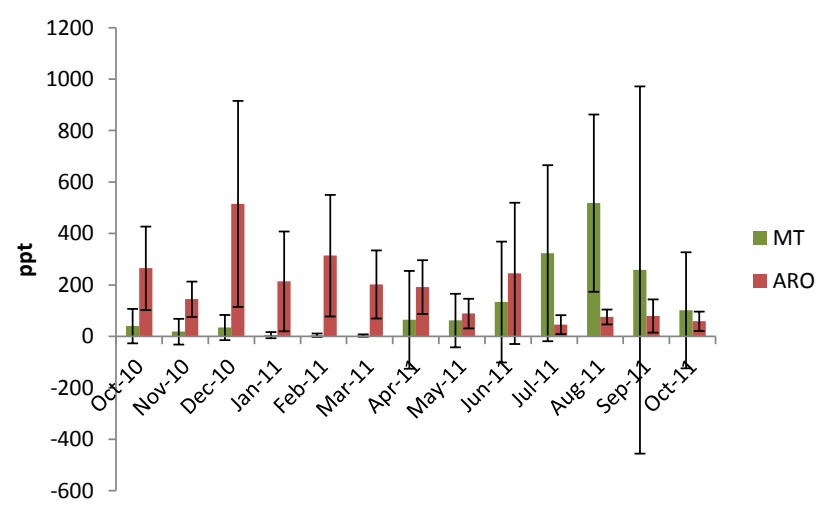

Fig. 1. Monthly mean mixing ratios and standard deviations of monoterpenes and aromatic hydrocarbons at Hyytiälä. Episodes are not included.

\section{Results and discussion}

\subsection{Annual variability of VOC mixing ratios}

Figure 1 shows the mean monthly mixing ratios of monoterpenes and aromatic hydrocarbons; these are also tabulated in the Appendix A together with the sesquiterpene mean monthly mixing ratios. Aromatic hydrocarbons are emitted from traffic and wood combustion (Hellén et al., 2006, 2008) and have maximum mixing ratios in winter due to slower sink reactions and larger emissions (e.g., heating with wood and cold starts of cars), whereas monoterpenes, in spite of their faster sink reaction, have maximum mixing ratios in summer due to larger emissions during the growing season. Sesquiterpenes have a summer maximum, but small amounts of sesquiterpenes were also measured in winter. The sesquiterpene summer maximum is in accordance with their emission rate maximum from Scots pine (Hakola et al., 2006b) and Norway spruce (Hakola et al., 2003).

During the winter months, mixing ratios of mono- and sesquiterpenes were low, very often below detection limits. Aromatic hydrocarbons were the main compound group; the mean winter mixing ratio of all aromatics was $270 \mathrm{ppt}$, whereas mono- and sesquiterpene winter mean mixing ratios were 8 and $2 \mathrm{ppt}$, respectively (occasional episodes not included). Monoterpene mixing ratios increased gradually in spring and reached a maximum in August (520 ppt). In July, measurements covered only the first week and, therefore, the maximum could have been reached earlier than in August. Sesquiterpene mixing ratios also had a maximum in August (2.3 ppt). Aromatic hydrocarbons were below $100 \mathrm{ppt}$ after June (about $60 \%$ of benzene was lost in June and July), and stayed at a low level until the measurements were finished in October 2011.

The main monoterpene in winter was camphene, followed by p-cymene, $\alpha$-pinene, and $\Delta^{3}$-carene (Fig. 2). The amount of p-cymene and camphene did not change much annually,
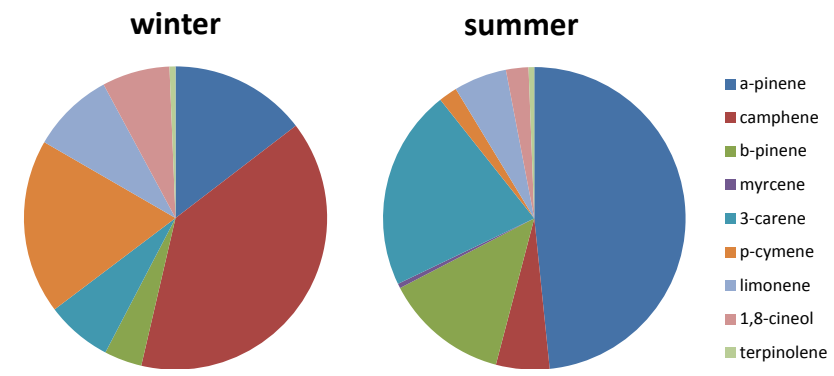

Fig. 2. The monoterpene distribution in winter and in summer at Hyytiälä.

the lowest mixing ratios being measured in February 2011, $1 \mathrm{ppt}$ both, and the highest in summer 2011, $11 \mathrm{ppt}$ in June for p-cymene and $28 \mathrm{ppt}$ for camphene in June. However, the mixing ratios of both of them increased in episodes, as described below in more detail. As spring proceeded, the contribution of camphene and p-cymene became less important, and by February the main monoterpene was already $\alpha$-pinene, followed by $\Delta^{3}$-carene. $\alpha$-Pinene and $\Delta^{3}$-carene are the main compounds emitted from Scots pines in Finland (Jansson et al., 1993; Rinne et al., 2000; Hakola et al., 2006b; Bäck et al., 2012). Limonene, $\beta$-pinene and 1,8cineol mixing ratios were only significant (monthly mean above $10 \mathrm{ppt}$ ) in summer and early autumn. 1,8-Cineol has been measured in the Scots pine emissions during summer only (Hakola et al., 2006b) whereas limonene and $\beta$-pinene have been detected also during spring and autumn, but with lesser amounts (Tarvainen et al., 2005). Myrcene was only detected in summer and in September. The mixing ratio of bornylacetate did not change over the course of a year, with its monthly mean mixing ratio staying below 3 ppt for the whole period.

To our knowledge there are no earlier data about sesquiterpene mixing ratios in air covering all seasons. Some sesquiterpenes are very reactive, their atmospheric lifetime being only a few minutes and, therefore, not all of them can be measured in ambient air. However, the less reactive ones, such as isolongifolene and longifolene, can be found at detectable levels. On the basis of emission rate measurements conducted at the SMEAR II station, $\beta$-caryophyllene is the most common sesquiterpene (Hakola et al., 2006b), but this is so reactive that it cannot be measured with current techniques.

The main sesquiterpenes measured were longifolene and isolongifolene (Fig. 3). The somewhat surprising sesquiterpene winter mixing ratios may be due to fluxes from the forest floor. Aaltonen et al. (2012) have measured sesquiterpene fluxes from the ground into the snowpack during the winter. In 2008-2009 the fluxes were quite small, especially close to the snow surface $\left(-0.96-0.08 \mathrm{ng} \mathrm{m}^{-2} \mathrm{~h}^{-1}\right)$. However, during the winter of 2009-2010, forest damage caused large sesquiterpene fluxes within the snowpack $\left(220 \mathrm{ng} \mathrm{m}^{-2} \mathrm{~h}^{-1}\right)$. 


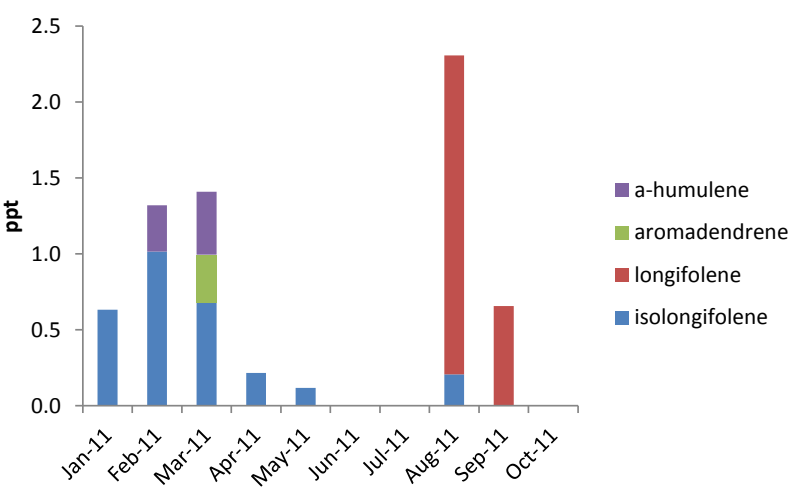

Fig. 3. The monthly mean mixing ratios of different sesquiterpene species at Hyytiälä. June and July measurements are missing due to chromatographic problems.

In the mid-summer period, sesquiterpenes are emitted from boreal trees (Hakola et al., 2006b; Ruuskanen et al., 2007; Tarvainen et al., 2007). Sesquiterpenes can also be released to the air as a result of forest management. Haapanala et al. (2012) have also detected sesquiterpene emissions from tree stumps. Sesquiterpene emissions have also been measured from the forest floor (Aaltonen et al., 2011; Hellén et al., 2006). Sesquiterpenes were also detected in June and July, but due to the bad peak shapes at the end of the chromatogramme at that time, the results were not quantitatively reliable and are, therefore, not shown.

Measurements also showed occasional monoterpene episodes, in which mixing ratios increased for couple of days or for just a few hours. On these occasions the wind speed was always low, but the wind direction varied between episodes. The closest sawmill is only about $5 \mathrm{~km}$ to the southeast of the site and a few of the mixing ratio increases can be attributed to this sawmill, but there were also other wind directions that were connected with monoterpene increases i.e., $\sim 350^{\circ}, \sim 200^{\circ}$ and about $50-100^{\circ}$. Liao et al. (2011) studied the anthropogenic influence on the ambient monoterpene mixing ratios at Hyytiälä and found a much more distinct connection with the closest sawmill than we did. Their measurements were made with a PTR-MS and, hence had a better time resolution. They also found somewhat increased mixing ratios in wind directions of $\sim 350^{\circ}, \sim 30^{\circ}$ and $\sim 200^{\circ}$. The city of Tampere is $50 \mathrm{~km}$ to the south-west and could cause elevated monoterpene mixing ratios. Monoterpenes are also emitted from traffic (Hellén et al., 2012). To the north-east $(25 \mathrm{~km})$ there is another sawmill that could also be responsible for monoterpene emissions. Figure 4 shows monoterpene data from December 2010 to February 2011. This figure includes several monoterpene episodes; the episodes are accompanied with increased $\mathrm{NO}_{\mathrm{x}}$ mixing ratios, thus, showing they are of anthropogenic origin. Three of the episodes in our measurements can be attributed to the closest sawmill (22 December 2010, 18 January 2011 and 23 February 2011).

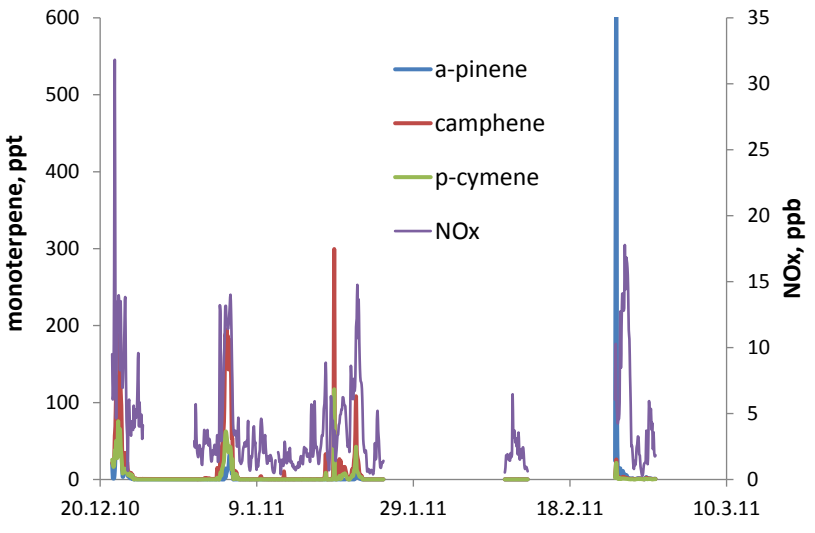

Fig. 4. Monoterpene winter episodes 18 December 2010-28 February 2011.

The dominant monoterpenes measured during the two first episodes were camphene and p-cymene, but in the last one $\alpha$-pinene. One episode originated from the east (4 January 2011), and one mainly from the south (21 January 2011). Again the major compounds were camphene and p-cymene. Ignoring these episodes, the monoterpene mixing ratios in winter were very low, most of the time below detection limits. Episodes were also seen during autumn a couple of times; again they were composed of camphene and p-cymene. Later in spring and in summer these peaks were no longer detected, possibly being masked by higher mixing ratios in the biologically-active season. In the whole dataset the highest monoterpene mixing ratios are measured in north-east-northwest sector and in south east (Fig. 5).

The monthly mean values in Figs. 1, 2 and 3 do not contain the episodes. The Appendix A contains monthly mean mixing ratios of all measured compounds both including episodes and excluding them.

\subsection{Enantiomeric structure of monoterpenes}

Williams et al. (2007) measured enantiomerically resolved monoterpene mixing ratios at Hyytiälä in April 2005. They found (+)- $\alpha$-pinene to be the dominant stereoisomer, of $\alpha$ pinene about $75 \%$ being $(+)-\alpha$-pinene and $25 \%(-)-\alpha$ pinene. Our results were similar, but the contribution of the + enantiomer was a little less than in the earlier study. At the same site, we took one ambient air sample each month during the growing season for determination of the enantiomeric structure of the $\alpha$-pinene and limonene (24 May 2011, 7 June 2011, 22 June 2011, 20 July 2011, 23 August 2011, 6 September 2011) (Fig. 6). On each occasion about $60 \%$ of the $\alpha$-pinene was $(+)-\alpha$-pinene. Limonene had more variability, but the variation had no trend during the growing season. In May about $50 \%$ was (-)-limonene, on 7 June all the limonene was (-)-limonene, in July and in August 
B

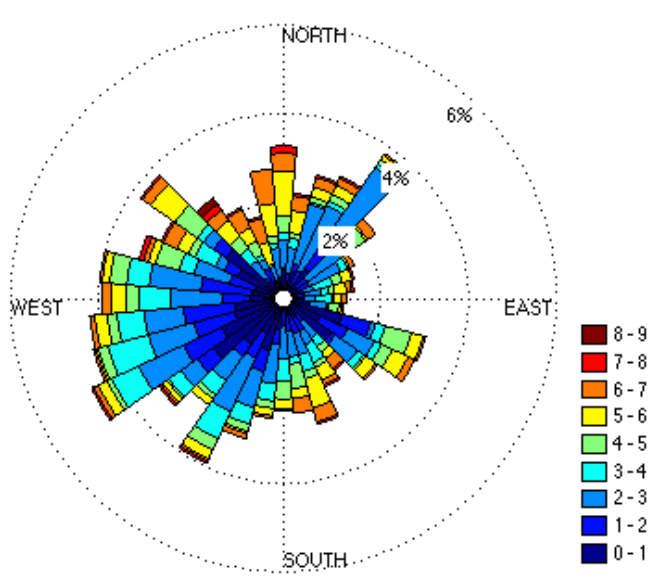

A

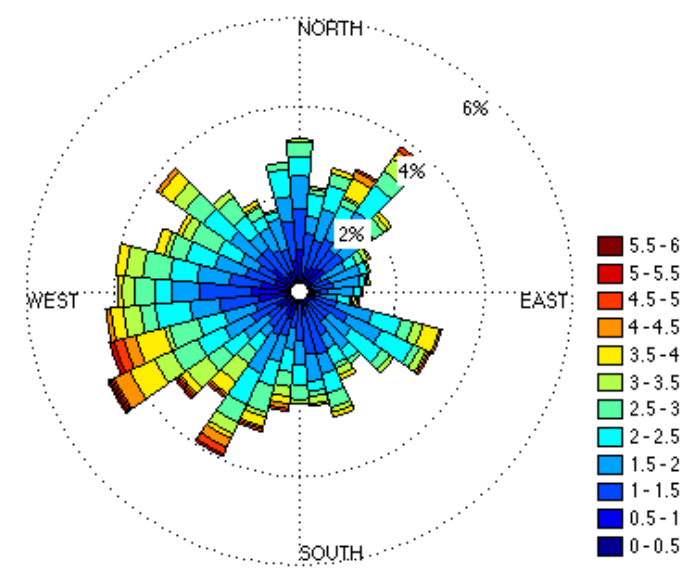

Fig. 5. Wind direction distribution (A) at Hyytiälä and monoterpene mixing ratio distribution in different wind direction (B). Monoterpene mixing ratios are presented in the logarithmic scale.

about $70 \%$ was $(-)-$ limonene, whereas limonene mixing ratio was below detection limit on 22 June and in September.

Williams et al. (2007) suggest that $(-)-\alpha$-pinene would be formed in a light-dependent way like isoprene, whereas $(+)-\alpha$-pinene would be released into the air in a temperature-dependent way. Our enantiomer samples were always taken at about midday and they were equally well correlated with isoprene mixing ratios, thus, not enlightening this hypothesis.

\subsection{Diurnal variations of VOC mixing ratios}

During the winter months there was no diurnal variability in any of the VOCs. The monoterpene mixing ratios above detection limits were associated with occasional episodes. In the middle of April, monoterpenes started to show a pro-
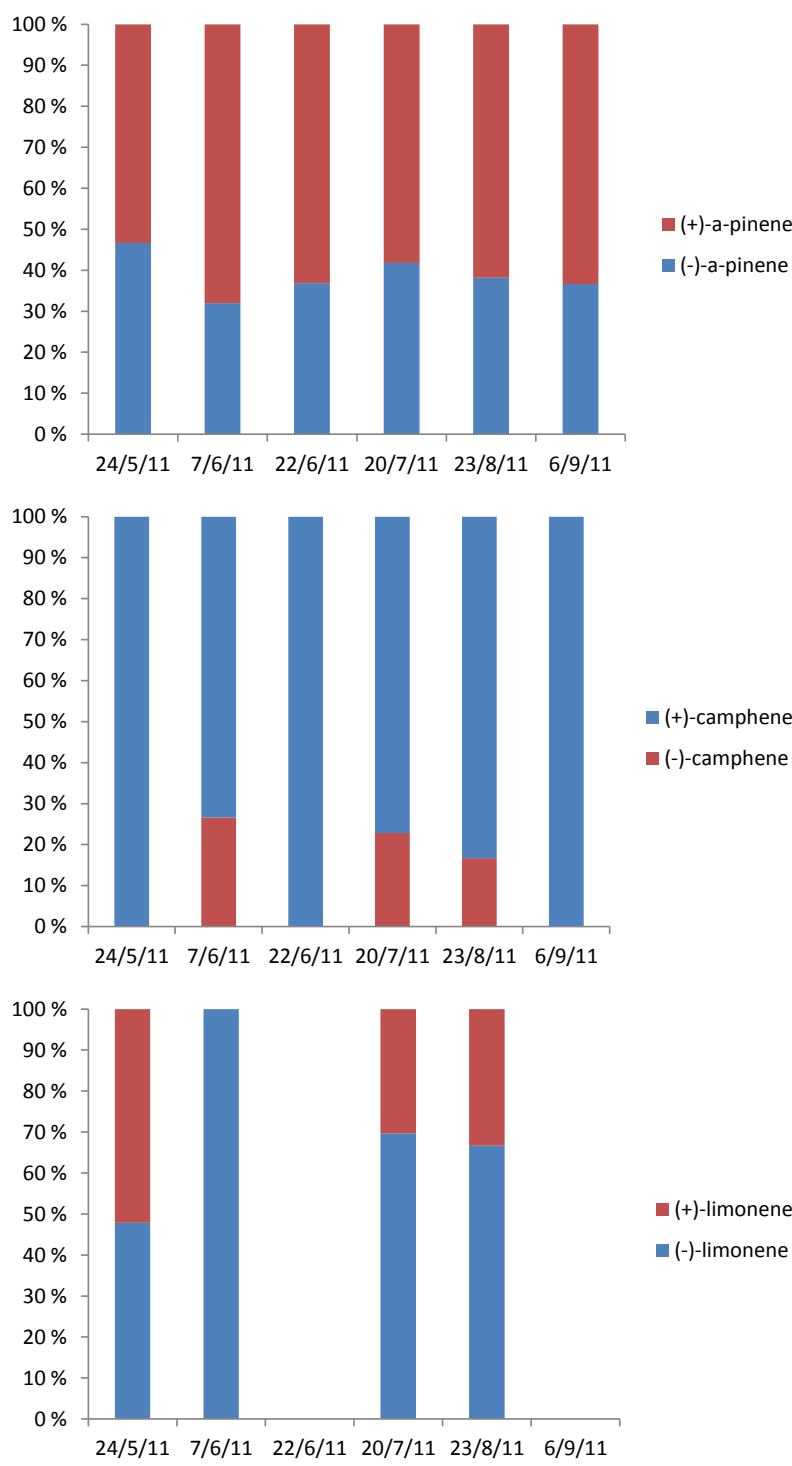

Fig. 6. The contribution of $(+)$ and (-) enantiomers in $\alpha$-pinene, limonene and camphene mixing ratios.

nounced diurnal variation, maximum mixing ratios occurring during the night and minima during the day (Fig. 7). March is not included in the figure, because mixing ratios in March recalled the low winter mixing ratios with no diurnal variation. Even though the emissions from Scots pine (the main tree species in the vicinity) are higher during the day (Holzke et al., 2006; Rinne et al., 2005; Taipale et al., 2011), the ambient air mixing ratios measured during the day were at their lowest, due to increased mixing and faster photochemical reactions.

In summer, the diurnal variability was similar to that in spring, except that the mixing ratios were higher, the total monoterpene mixing ratio being $670 \mathrm{ppt}$ at night and $60 \mathrm{ppt}$ in the daytime (Fig. 8). This is due to the higher emissions 

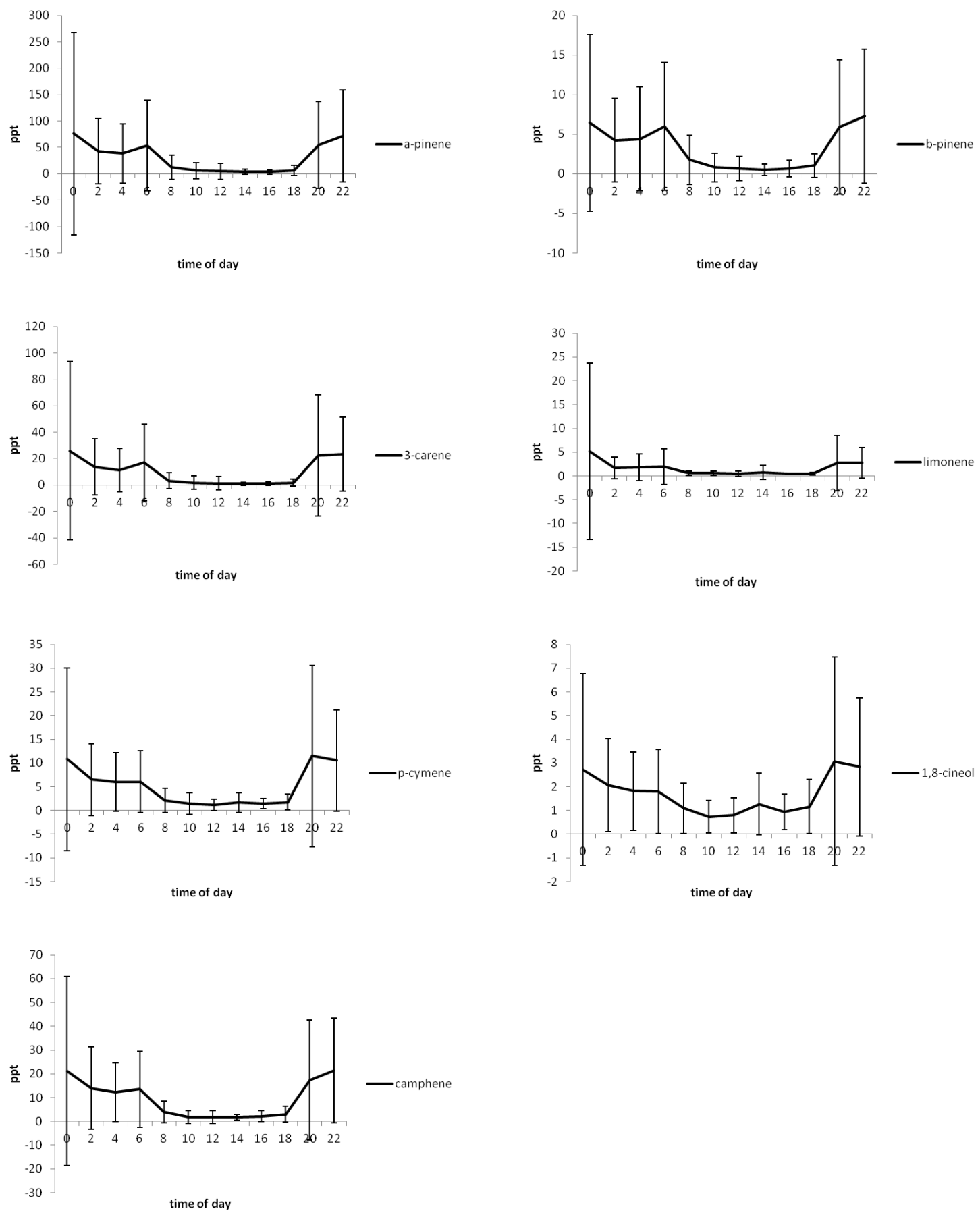

Fig. 7. The mean diurnal variability and standard deviations of monoterpenes in spring (April, May). March is not included in the figure, because mixing ratios then are more like winter mixing ratios, with no diurnal variability.

in summer. The highest hourly monoterpene mixing ratios in summertime were generally observed during periods with the lowest friction velocities, and vice versa (Fig. 9). As the friction velocity tends to be lower at night, the higher mixing ratios are mainly found at night-time. It is noteworthy that low daytime friction velocities are also often associated with high monoterpene mixing ratios. Friction velocity is a good estimate for mixing and boundary layer height. The smaller the friction velocity the smaller the BL heigh and vice versa. Each monoterpene species also showed similar behaviour separately. In contrast, isoprene mixing ratios did 

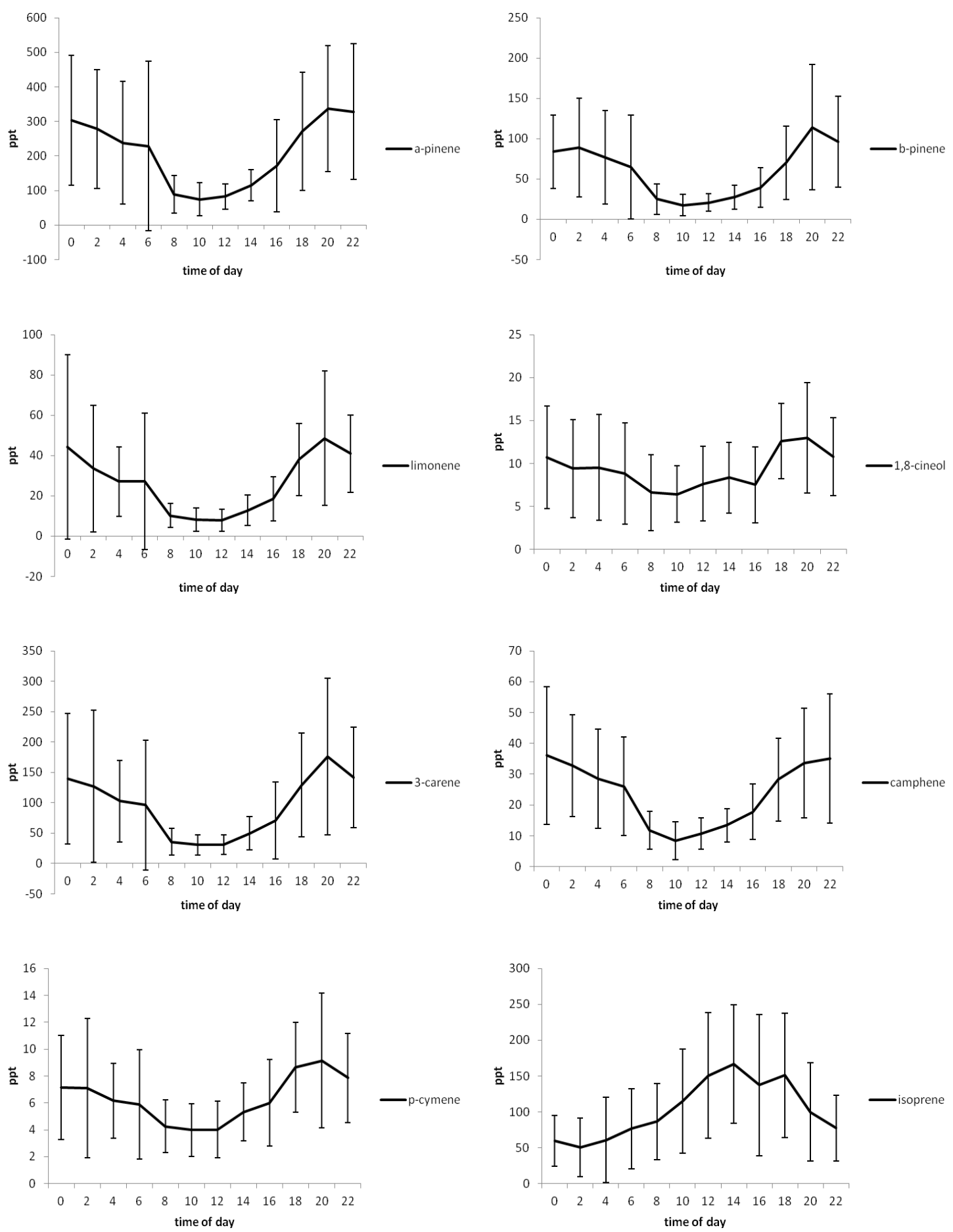

Fig. 8. The mean diurnal variability and standard deviations of monoterpenes and isoprene in summer (June, July, August). (Isoprene mixing ratios are underestimates due to breakthrough of the cold trap.)

not show this kind of behaviour, but were generally lowest in the night and highest in the afternoon.

Isoprene is formed and emitted only in light conditions and is not, therefore, emitted during the night. A signifi- cant part of the monoterpene emission originates from large storages and is, thus, controlled by temperature via the saturation vapour pressure of monoterpenes (Ghirardo et al., 2010). This leads to significant night-time emission, albeit 


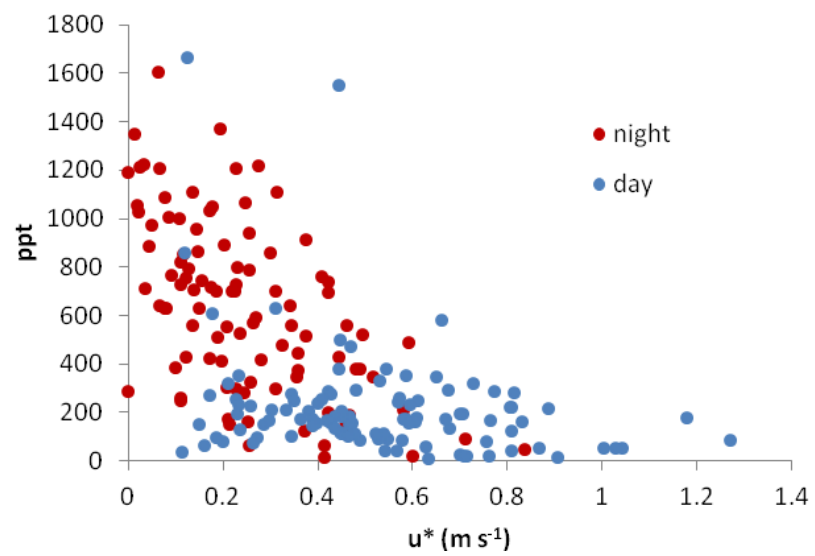

Fig. 9. The monoterpene mixing ratio dependence on friction velocity in June, July and August.

lower than daytime emissions. Thus, the diurnal cycle of isoprene mixing ratio is the opposite to that of the monoterpenes. Since sesquiterpene mixing ratios showed a similar diurnal profile to that of the monoterpenes (Fig. 10), emissions are not likely to be totally under the control of light. Jardine et al. (2011) measured mono- and sesquiterpene mixing ratios in Amazonia, and Jones et al. (2011) isoprene and monoterpenes in an Asian tropical forest. In the Asian tropics the monoterpene diurnal variation had a daytime maximum, like isoprene in our measurements, indicating lightdependent emissions there, as observed by Kuhn et al. (2002) and Rinne et al. (2002). Sesquiterpenes in Amazonia had a night maximum as did those at Hyytiälä. Bouvier-Brown et al. (2009) measured diurnal profiles with day minima for most of the sesquiterpenes in California.

In autumn the diurnal variability continued to be similar to that in spring and summer, but the mixing ratios were lower. The total monoterpene mixing ratio was $15 \mathrm{ppt}$ during the day and $110 \mathrm{ppt}$ at night, i.e., of the same order of magnitude as in spring.

\subsection{Reactivity of VOCs}

According to Hakola et al. (2006b), the monthly mean VOC emission potentials $\left(30^{\circ} \mathrm{C}\right)$ of Scots pine trees at Hyytiälä were $0.1,0.3$ and $0.06 \mu \mathrm{g} \mathrm{g}_{\text {(needle dry weight) }}^{-1} \mathrm{~h}^{-1}$ for SQT in June, July and August, and 1.3, 1.0 and 0.45 for monoterpenes in June, July and August, respectively. Scots pine is the main tree species in the area and the SQT/MT emission ratio is $8 \%, 30 \%$ and $13 \%$ in June, July and August, respectively. In ambient mixing ratios this ratio is much lower, i.e., $1.9 \%, 1.3 \%$ and $0.5 \%$, reflecting the higher reactivity of the SQTs. The difference in reactivity is mainly due to the very rapid destruction of some sesquiterpenes $(\beta$ caryophyllene and $\alpha$-humulene in particular) in the ozone reaction. The reaction rate constants are shown in Table 1. $\beta$ caryophyllene is the main sesquiterpene found in Scots pine

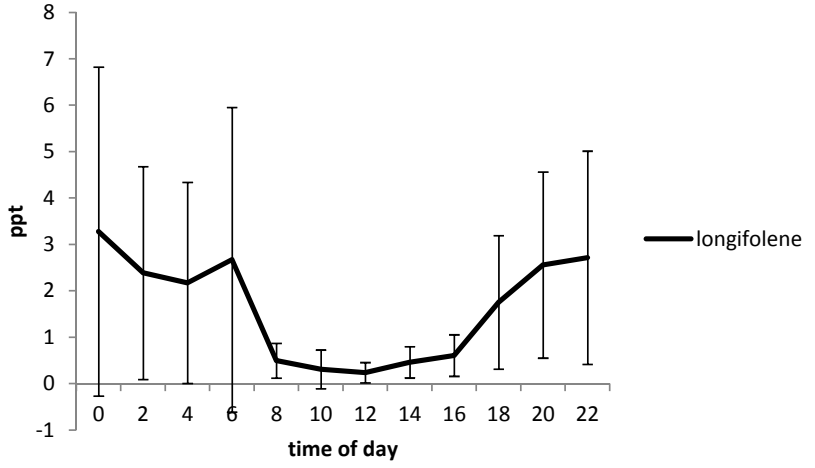

Fig. 10. The mean diurnal variability and standard deviations of longifolene in August.

emissions, but it was not measured in the ambient air. Other sesquiterpenes react more slowly and, for example, longifolene's atmospheric lifetime in the ozone reaction is $>23$ days (Shu and Atkinson, 1995); it was also the main sesquiterpene in air during the summer. In their reactions with ozone, mono- and sesquiterpenes form secondary organic aerosol mass (Hoffmann et al., 1997; Bonn and Moortgat, 2003), the fast-reacting $\beta$-caryophyllene and $\alpha$-humulene in particular having a high aerosol-forming potential. However, due to their high reactivity, their effect on the ozone reaction has to be evaluated from emission rate measurements instead of from the ambient mixing ratios. Figure 11 shows the monthly means of the destruction rates between ozone and BVOCs,

$R=k_{\mathrm{X}, \mathrm{O}_{3}}[\mathrm{X}]\left[\mathrm{O}_{3}\right]$,

where $k_{\mathrm{X}, \mathrm{O}_{3}}$ is the reaction rate constant between $\mathrm{X}$ and $\mathrm{O}_{3}$, $[\mathrm{X}]$ is the VOC mixing ratio and $\left[\mathrm{O}_{3}\right]$ is the ozone mixing ratio. Aromatic hydrocarbons do not react with ozone, so ozone reacted mainly with monoterpenes, only isoprene having about a $5-10 \%$ share in the ozone reaction in summer. Although the terpinolene and limonene mixing ratios in air are low, they make a substantial contribution to ozone chemistry.

The reaction rate coefficients of hydroxyl radicals with isoprene, the monoterpenes and the sesquiterpenes are of the same order of magnitude and all of the compound groups affect hydroxyl radical reactivity. Hydroxyl radicals were not measured, but $\mathrm{OH}$ reactivities of different compound groups to $\mathrm{OH}$ reactivity are shown in Fig. 12,

reactivity $=k_{\mathrm{X}, \mathrm{OH}}[\mathrm{X}]$

where $k_{\mathrm{X}, \mathrm{OH}}$ is the reaction rate constant between $\mathrm{X}$ and $\mathrm{OH}$ and $[\mathrm{X}]$ is the VOC mixing ratio. In summer, isoprene dominates hydroxyl radical reactivity, because it has a day maximum, when hydroxyl radical reactions occur, whereas monoterpene mixing ratios are low during the day. Ortega et al. (2007) measured branch-level VOC emission rates in 


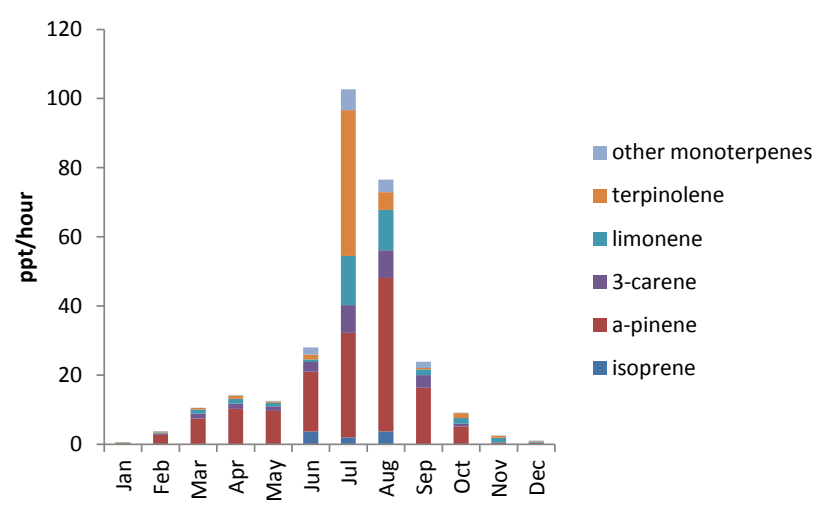

Fig. 11. Monthly means of destruction rates in reactions between ozone and the monoterpenes and isoprene.

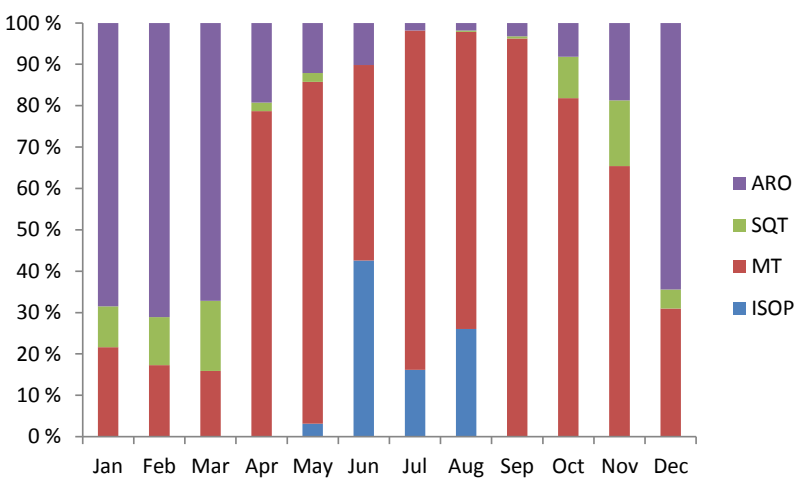

Fig. 12. Relative contribution of different BVOC groups to the $\mathrm{OH}$ reactivity. Sesquiterpene contribution is missing in June and July due to chromatographic problems.

a mixed northern hardwood forest and evaluated $\mathrm{OH}$ reactivity on the basis of their measurements. They also found that isoprene dominated the hydroxyl radical reactivity there. Aromatic hydrocarbons make a large contribution in winter, when also the most reactive aromatics, for example trimethylbenzenes, exist in the air. MT and SQT contribute the year round.

Probable oxidation with $\mathrm{OH}$ radicals has a significant contribution to atmospheric new particle formation and subsequent growth (e.g., Kulmala et al., 1998, 2004a, b).

\subsection{Comparison with earlier results}

Mixing ratios of monoterpenes and aromatic hydrocarbons have been measured earlier at Hyytiälä during the years 2000-2007. The measurements were based on adsorbent tube sampling and subsequent analysis in a laboratory. Two samples were collected at about midday at weekly intervals (Hakola et al., 2009). The samples were collected from a tower just above the forest canopy. The forest grew during the seven years of measurements, and during the last years
Table 1. Reaction rate coefficient of VOCs with hydroxyl radical and ozone.

\begin{tabular}{|c|c|c|}
\hline \multirow[t]{2}{*}{ VOC } & \multicolumn{2}{|c|}{ rate constant $\left(\mathrm{cm}^{3}\right.$ molecule $\left.{ }^{-1} \mathrm{~s}^{-1}\right)$} \\
\hline & $\mathrm{OH}$ & $\mathrm{O}_{3}$ \\
\hline Isoprene & $1.01 \times 10^{-10}$ & $1.3 \times 10^{-17}$ \\
\hline \multicolumn{3}{|c|}{ monoterpenes } \\
\hline Camphene & $5.3 \times 10^{-11}$ & $9.0 \times 10^{-19}$ \\
\hline$\Delta 3$-carene & $8.8 \times 10^{-11}$ & $37 \times 10^{-18}$ \\
\hline p-cymene & $1.5 \times 10^{-11}$ & $5.0 \times 10^{-20}$ \\
\hline Limonene & $171 \times 10^{-12}$ & $2.0 \times 10^{-16}$ \\
\hline myrcene & $21.5 \times 10^{-11}$ & $47 \times 10^{-17}$ \\
\hline$\alpha$-pinene & $5.37 \times 10^{-11}$ & $8.66 \times 10^{-17}$ \\
\hline$\beta$-pinene & $7.89 \times 10^{-11}$ & $1.5 \times 10^{-17}$ \\
\hline terpinolene & $225 \times 10^{-12}$ & $1.38 \times 10^{-16}$ \\
\hline \multicolumn{3}{|c|}{ sesquiterpenes } \\
\hline alloaromadendrene & $62 \times 10^{-12}$ & $1.2 \times 10^{-17}$ \\
\hline aromadendrene & $6.25 \times 10^{-11}$ & $1.20 \times 10^{-17}$ \\
\hline$\beta$-caryophyllene & $200 \times 10^{-12}$ & $44.2 \times 10^{-17}$ \\
\hline$\alpha$-humulene & $29 \times 10^{-11}$ & $87 \times 10^{-17}$ \\
\hline isolongifolene & $96 \times 10^{-12}$ & $1.14 \times 10^{-17}$ \\
\hline longicyclene & $9.40 \times 10^{-12}$ & \\
\hline longifolene & $4.7 \times 10^{-11}$ & $1.10 \times 10^{-17}$ \\
\hline \multicolumn{3}{|c|}{ aromatics } \\
\hline benzene & $1.23 \times 10^{-12}$ & $1.7 \times 10^{-22}$ \\
\hline toluene & $5.96 \times 10^{-12}$ & $4.1 \times 10^{-22}$ \\
\hline ethylbenzene & $7.1 \times 10^{-12}$ & \\
\hline p-xylene & $1.47 \times 10^{-11}$ & $1.0 \times 10^{-21}$ \\
\hline m-xylene & $2.36 \times 10^{-11}$ & \\
\hline o-xylene & $1.37 \times 10^{-11}$ & $1.7 \times 10^{-21}$ \\
\hline styrene & $5.8 \times 10^{-11}$ & \\
\hline propylbenzene & $6.0 \times 10^{-12}$ & \\
\hline 2-Ethyltoluene & $1.23 \times 10^{-11}$ & \\
\hline 3-ethyltoluene & $1.92 \times 10^{-11}$ & \\
\hline 4-Ethyltoluene & $1.21 \times 10^{-11}$ & \\
\hline 1,3,5-TMB & $5.75 \times 10^{-11}$ & \\
\hline 1,2,4-TMB & $3.25 \times 10^{-11}$ & \\
\hline
\end{tabular}

The rate constants are from Atkinson (1994) except those for $\beta$-caryophyllene, $\alpha$-humulene and longifolene $\mathrm{OH}$ reaction rates, which are from Shu and Atkinson (1995).

Other sesquiterpene data is from CSID: 1406720 ,

http://www.chemspider.com/Chemical-Structure.1406720.html (last access: 12:32, 4 June 2012). Predicted data is generated using the US Environmental Protection Agency's EPI Suite.

Ozone reactions of aromatic hydrocarbons are of negligible importance.

the measurements represented the air inside the forest canopy rather than that above it and, for that reason, the mixing ratios increased during the time period. Other activities in the vicinity are also likely to have added to the mixing ratio increase. In the present study, the samples were collected in an open area about four metres outside of the forest at a height of about $2.5 \mathrm{~m}$. We, therefore, compare the present results 
Table 2. Comparison of the present results (afternoon values only and daily means) to the earlier measurements (2000-2003) conducted at Hyytiälä (Hakola et al., 2009).

\begin{tabular}{|c|c|c|c|c|c|c|c|c|c|c|c|c|}
\hline \multirow[b]{2}{*}{ PPTV } & \multicolumn{4}{|c|}{ 2000-2003, afternoon } & \multicolumn{4}{|c|}{ 2010-2011, afternoon } & \multicolumn{4}{|c|}{ 2010-2011, daily mean } \\
\hline & winter & spring & summer & autumn & winter & spring & summer & autumn & winter & spring & summer & autumn \\
\hline a-pinene & 52 & 69 & 107 & 110 & 5 & 3 & 71 & 23 & 6 & 32 & 189 & 38 \\
\hline camphene & 7 & 3 & 9 & 13 & 15 & 2 & 9 & 8 & 12 & 11 & 22 & 11 \\
\hline b-pinene & 14 & 12 & 25 & 22 & 0 & 0 & 17 & 4 & 1 & 3 & 52 & 7 \\
\hline 3-carene & 29 & 34 & 63 & 54 & 3 & 1 & 30 & 14 & 4 & 11 & 84 & 19 \\
\hline limonene & 0 & 0 & 0 & 3 & 3 & 1 & 7 & 3 & 2 & 2 & 22 & 4 \\
\hline 1,8-cineol & 2 & 1 & 24 & 1 & 1 & 1 & 12 & 2 & 1 & 2 & 9 & 2 \\
\hline terpinolene & 0 & 0 & 2 & 0 & 0 & 0 & 1 & 0 & 0 & 0 & 2 & 0 \\
\hline bornylacetate & 2 & 2 & 11 & 2 & 1 & 0 & 0 & 0 & 1 & 0 & 1 & 0 \\
\hline
\end{tabular}

with those of the years 2000-2003, when samples were taken above the canopy and prior to forest felling in the vicinity (Table 2). The main differences are to be found in the mixing ratios of $\alpha$-pinene and $\Delta^{3}$-carene, which were higher in the earlier measurements during all other seasons except summer. Also, camphene was not the dominant compound in winter. The differences during summer are rather small, in spite of the different measurement heights and locations (about $100 \mathrm{~m}$ apart from each other), but in other seasons the current mixing ratios are much lower than those measured earlier. Rinne et al. (2005) measured monoterpene mixing ratios at Hyytiälä in July 2004 with a proton transfer reaction mass spectrometer (PTR-MS) also at a height of about two metres. The daytime monoterpene mixing ratios they measured varied between 200-500 ppt, and night-time mixing ratios frequently reached $1 \mathrm{ppb}$. This is in accordance with our results.

Recently Seco et al. (2011) have published monoterpene mixing ratios from the Western Mediterranean area during winter and summer using PTR-MS. They report monoterpene summer and winter mean mixing ratios of $0.64 \mathrm{ppb}$ and $0.03 \mathrm{ppb}$, respectively. These mixing ratios are at about the same level as ours, i.e., summer $0.38 \mathrm{ppb}$ and winter $0.03 \mathrm{ppb}$, although emission rates in warmer climates are higher implying more efficient sink reactions as well.

\section{Conclusions}

Isoprene, mono- and sesquiterpene and aromatic hydrocarbon mixing ratios were measured in a boreal pine forest using an in situ gas chromatograph mass-spectrometer. The measurements covered the whole year, at least one week every month. To our knowledge there are no earlier speciesspeciated semi-continuous BVOC data also covering dormant periods.
During the winter months, and still in March, the mixing ratios of all biogenic compounds were very low, most of the time below detection limits. Occasionally, the mixing ratios of monoterpenes, particularly camphene and p-cymene, increased together with $\mathrm{NO}_{\mathrm{x}}$ mixing ratios, implying an anthropogenic source. These episodes lasted from a few hours to few days and were originated from nearby sawmills or the city of Tampere.

The monoterpene mixing ratios increased in April and started to show diurnal variability, with maximum mixing ratios at night and minima during the day as expected, since Scots pine VOC emissions are only temperature-dependent. The diurnal variability continued until October, after which the mixing ratios decreased, with only occasional episodes taking place. The diurnal variation was affected by the friction velocity, high mixing ratios being found with low friction velocities and low mixing ratios being observed high friction velocities.

Sesquiterpenes diurnal curve was measured for the first time in boreal areas and was similar as that of monoterpenes. The main sesquiterpenes were longifolene and isolongifolene.

The diurnal variation of isoprene was opposite to the mono- and sesquiterpene diurnal curve, due to its totally light-dependent emissions. Due to its daytime maximum mixing ratios, isoprene also dominated hydroxyl radical reactivity in summer even though our isoprene measurements are underestimates due to breakthrough in a cold trap. 


\section{Appendix A}

Table A1. Monthly mean mixing ratios of VOCs (ppt). The months with high episodes mean values are calculated separately including and excluding the episodes. Sesquiterpene mixing ratios were not available in June and July due to bad chromatography.

\begin{tabular}{|c|c|c|c|c|c|c|c|c|c|}
\hline & Oct-10 & $\begin{array}{l}\text { Nov-10 } \\
\text { exc.epis. }\end{array}$ & $\begin{array}{l}\text { Nov-10 } \\
\text { inc.epis. }\end{array}$ & $\begin{array}{l}\text { Dec-10 } \\
\text { exc.epis. }\end{array}$ & $\begin{array}{l}\text { Dec-10 } \\
\text { inc.epis. }\end{array}$ & $\begin{array}{c}\text { Jan-11 } \\
\text { exc.epis. }\end{array}$ & $\begin{array}{c}\text { Jan-11 } \\
\text { inc.epis. }\end{array}$ & $\begin{array}{c}\text { Feb-11 } \\
\text { exc.epis. }\end{array}$ & $\begin{array}{r}\text { Feb-11 } \\
\text { inc.epis. }\end{array}$ \\
\hline \multicolumn{10}{|l|}{ monoterpenes } \\
\hline a-pinene & 8.1 & 2.3 & 3.1 & 5.5 & 21 & bdl & 1.1 & 2.0 & 13.8 \\
\hline camphene & 12 & 4.9 & 7.8 & 12 & 31 & 2.9 & 12 & 0.7 & 1.3 \\
\hline b-pinene & 2.8 & 1.2 & 1.7 & 0.9 & 1.0 & 0.2 & 0.1 & 0.6 & 2.0 \\
\hline myrcene & bdl & bdl & bdl & bdl & bdl & bdl & bdl & bdl & bdl \\
\hline 3-carene & 1.7 & 0.8 & 2.6 & 4.3 & 18 & bdl & 1.2 & 0.4 & 4.2 \\
\hline p-cymene & 4.7 & 3.9 & 7.0 & 7.4 & 15 & 1.0 & 3.7 & 0.5 & 0.9 \\
\hline limonene & 5.8 & 2.6 & 3.9 & 2.5 & 8.4 & bdl & 1.2 & bdl & bdl \\
\hline terpinolene & 1.1 & 0.1 & 1.2 & bdl & 0.1 & bdl & bdl & bdl & bdl \\
\hline \multicolumn{10}{|l|}{ oxygenated monoterpenes } \\
\hline 1,8-cineol & 4.1 & 2.9 & 3.7 & 2.7 & 3.0 & 0.3 & 0.4 & 0.5 & 0.5 \\
\hline bornylacetate & 1.7 & 0.6 & 2.0 & 2.5 & 2.8 & 0.5 & 0.5 & 0.7 & 0.7 \\
\hline \multicolumn{10}{|l|}{ sesquiterpenes } \\
\hline longicyclene & 2.2 & 0.8 & 2.2 & 1.4 & 1.9 & bdl & bdl & bdl & bdl \\
\hline isolongifolene & 2.3 & 0.9 & 2.9 & 1.7 & 2.3 & 0.6 & 0.7 & 1.0 & 1.0 \\
\hline longifolene & 1.9 & 0.2 & 1.7 & bdl & bdl & bdl & bdl & bdl & bdl \\
\hline aromadendrene & 2.2 & 0.5 & 1.6 & 0.6 & 1.0 & bdl & bdl & bdl & bdl \\
\hline a-humulene & 1.4 & 0.4 & 2.4 & bdl & bdl & bdl & bdl & 0.3 & 0.3 \\
\hline alloaromadendrene & 1.5 & 0.3 & 2.2 & 0.6 & 2.8 & bdl & bdl & bdl & bdl \\
\hline \multicolumn{10}{|l|}{ aromatics } \\
\hline benzene & 210 & 118 & 119 & 142 & 160 & 111 & 123 & 190 & 196 \\
\hline toluene & 53 & 26 & 29 & 179 & 219 & 69 & 85 & 79 & 85 \\
\hline Ethylbenzene & bdl & bdl & bdl & 30 & 38 & 6.9 & 9.9 & 9.2 & 9.8 \\
\hline p/m-xylene & bdl & bdl & bdl & 77 & 100 & 13 & 19 & 16 & 17 \\
\hline o-xylene & bdl & bdl & bdl & 8.7 & 10.9 & 2.1 & 2.5 & 3.6 & 3.9 \\
\hline Styrene & bdl & bdl & bdl & 40 & 52 & 6.8 & 11 & 8.7 & 9.5 \\
\hline Propylbenzene & bdl & bdl & bdl & 7.5 & 29 & 1.5 & 2.5 & 1.4 & 1.6 \\
\hline 2-ethyltoluene & bdl & bdl & bdl & 9.8 & 5.3 & 1.2 & 1.2 & 1.7 & 1.2 \\
\hline 3-ethyltoluene & bdl & bdl & bdl & bdl & 14 & 0.8 & 2.4 & 0.9 & 1.8 \\
\hline 4-ethyltoluene & bdl & bdl & bdl & bdl & bdl & 0.3 & 1.8 & 0.4 & 1.0 \\
\hline 1.3.5-trimethylbenzene & bdl & 0.1 & bdl & 3.8 & bdl & 0.7 & 0.7 & 1.0 & 0.4 \\
\hline 1,2,4-trimethylbenzene & bdl & bdl & bdl & 15 & 21 & 1.1 & 3.0 & 1.8 & 2.0 \\
\hline 1,2,3-trimethylbenzene & bdl & bdl & bdl & 2.4 & 3.0 & 0.2 & 0.5 & 0.5 & 0.6 \\
\hline MT & 36 & 16 & 27 & 32 & 96 & 5 & 19 & 5 & 23 \\
\hline oxy-MT & 5.8 & 3.5 & 5.7 & 5.2 & 5.7 & 0.8 & 0.9 & 1.2 & 1.3 \\
\hline SQT & 11 & 3.1 & 13 & 4.2 & 8.0 & 0.6 & 1.7 & 1.3 & 2.2 \\
\hline ARO & 265 & 145 & 150 & 515 & 653 & 214 & 262 & 314 & 330 \\
\hline
\end{tabular}


Table A1. Continued.

\begin{tabular}{|c|c|c|c|c|c|c|c|c|c|}
\hline & $\begin{array}{c}\text { Mar-11 } \\
\text { exc.epis. }\end{array}$ & $\begin{array}{l}\text { Mar-11 } \\
\text { inc.epis. }\end{array}$ & Apr-11 & May-11 & Jun-11 & Jul-11 & Aug-11 & Sep-11 & Oct-11 \\
\hline \multicolumn{10}{|l|}{ monoterpenes } \\
\hline a-pinene & 1.0 & 26 & 34 & 30 & 68 & 126 & 259 & 131 & 51 \\
\hline camphene & 0.8 & 14 & 8.1 & 11.0 & 13 & 16 & 28 & 19 & 11 \\
\hline b-pinene & bdl & 0.6 & 3.3 & 3.3 & 8.7 & 44 & 72 & 21 & 9.4 \\
\hline myrcene & bdl & bdl & bdl & bdl & 1.7 & 3.2 & 1.6 & 1.5 & bdl \\
\hline 3-carene & 0.2 & 12 & 11 & 9.8 & 26 & 80 & 109 & 71 & 22 \\
\hline p-cymene & 0.7 & 6.6 & 5.0 & 5.2 & 11 & 5.7 & 7.1 & 7.4 & 4.4 \\
\hline limonene & bdl & 1.8 & 2.1 & 1.3 & 1.4 & 25.1 & 29.5 & 5.6 & 1.7 \\
\hline terpinolene & bdl & bdl & 0.1 & bdl & 0.2 & 7.9 & 1.4 & 0.2 & bdl \\
\hline \multicolumn{10}{|l|}{ oxygenated monoterpenes } \\
\hline 1,8-cineol & 0.47 & 0.52 & 1.59 & 1.87 & 2.61 & 16 & 10 & 1.27 & 0.52 \\
\hline bornylacetate & 0.59 & 0.59 & 0.17 & bdl & 0.13 & 1.77 & 0.29 & bdl & bdl \\
\hline \multicolumn{10}{|l|}{ sesquiterpenes } \\
\hline longicyclene & bdl & bdl & bdl & bdl & na & na & bdl & bdl & bdl \\
\hline isolongifolene & 0.7 & 0.6 & 0.2 & 0.1 & na & na & 0.2 & bdl & bdl \\
\hline longifolene & bdl & bdl & bdl & bdl & na & na & 2.1 & 0.7 & bdl \\
\hline aromadendrene & 0.3 & 0.3 & bdl & bdl & na & na & bdl & bdl & bdl \\
\hline a-humulene & 0.4 & 0.4 & bdl & bdl & na & na & bdl & bdl & bdl \\
\hline alloaromadendrene & bdl & bdl & bdl & bdl & na & na & bdl & bdl & bdl \\
\hline \multicolumn{10}{|l|}{ aromatics } \\
\hline benzene & 112 & 106 & 103 & 39 & 87 & 11 & 15 & 19 & 25 \\
\hline toluene & 57 & 60 & 56 & 32 & 88 & 10 & 22 & 40 & 27 \\
\hline Ethylbenzene & 6.4 & 6.2 & 5.1 & 2.1 & 7.1 & 0.7 & 2.7 & 3.0 & 1.2 \\
\hline $\mathrm{p} / \mathrm{m}$-xylene & 12 & 11 & 11 & 4 & 17 & 1 & 5 & 7 & 1 \\
\hline o-xylene & 3.1 & 2.9 & 7.4 & 6.6 & 27 & 13 & 21 & 3.9 & 1.1 \\
\hline Styrene & 5.5 & 5.6 & 4.9 & 2.2 & 10 & 1.0 & 2.8 & 2.8 & 1.1 \\
\hline Propylbenzene & 0.7 & 3.0 & 1.9 & 2.0 & 2.2 & 3.6 & 3.3 & 2.0 & 0.6 \\
\hline 2-ethyltoluene & 3.8 & 0.6 & 0.8 & 0.4 & 1.1 & 0.3 & 0.7 & 0.4 & 0.2 \\
\hline 3-ethyltoluene & 0.5 & 3.2 & 0.3 & 0.1 & 0.4 & 1.6 & 0.2 & 0.1 & bdl \\
\hline 4-ethyltoluene & 0.2 & 0.5 & 0.2 & 0.2 & 0.4 & 1.7 & 0.3 & 0.3 & bdl \\
\hline 1.3.5-trimethylbenzene & 0.6 & 0.3 & 0.4 & 0.2 & 0.6 & 0.8 & 1.4 & 0.6 & bdl \\
\hline 1,2,4-trimethylbenzene & 1.0 & 1.1 & 0.8 & 0.3 & 0.8 & 0.6 & 1.0 & 0.4 & bdl \\
\hline 1,2,3-trimethylbenzene & 0.3 & 0.4 & 0.4 & 0.2 & 0.6 & 0.1 & 0.5 & 0.2 & bdl \\
\hline MT & 2.6 & 61 & 63 & 60 & 129 & 308 & 508 & 257 & 99 \\
\hline oxy-MT & 1.1 & 1.1 & 1.8 & 1.9 & 2.7 & 18 & 10 & 1.3 & 0.5 \\
\hline SQT & 1.4 & 1.3 & 0.2 & 0.1 & na & na & 2.3 & 0.7 & bdl \\
\hline ARO & 202 & 202 & 192 & 89 & 241 & 46 & 76 & 80 & 58 \\
\hline
\end{tabular}


Acknowledgements. The financial support by the Academy of Finland Centre of Excellence programme (project no. 1118615) is gratefully acknowledged.

Edited by: N. Saigusa

\section{References}

Aaltonen, H., Pumpanen, J., Pihlatie, M., Hakola, H., Hellén, H., and Bäck, J.: Emissions of biogenic volatile organic compounds from boreal Scots pine forest floor, Agr. Forest Meteorol., 151, 682-691, 2011.

Aaltonen, H., Pumpanen, J., Hakola, H., Vesala, T., Rasmus, S., and Bäck, J.: Snowpack concentrations and estimated fluxes of volatile organic compounds in a boreal forest, Biogeosciences Discuss., 9, 527-555, doi:10.5194/bgd-9-527-2012, 2012.

Atkinson, R.: Gas-phase tropospheric chemistry of organic compounds. Journal of physical and chemical reference data, Monograph, 2, 216 pp., 1994.

Bonn, B., Kulmala, M., Riipinen, I., Sihto, S.-L., and Ruuskanen, T.: How biogenic terpenes govern the correlation between sulphuric acid concentrations and new particle formation, J. Geophys. Res., 113, D12209, doi:10.1029/2007JD009327, 2008.

Bouvier-Brown, N. C., Goldstein, A. H., Gilman, J. B., Kuster, W. C., and de Gouw, J. A.: In-situ ambient quantification of monoterpenes, sesquiterpenes, and related oxygenated compounds during BEARPEX 2007: implications for gas- and particle-phase chemistry, Atmos. Chem. Phys., 9, 5505-5518, doi:10.5194/acp-9-5505-2009, 2009.

Bäck, J., Aalto, J., Henriksson, M., Hakola, H., He, Q., and Boy, M.: Chemodiversity of a Scots pine stand and implications for terpene air concentrations, Biogeosciences, 9, 689-702, doi:10.5194/bg-9-689-2012, 2012.

Ghirardo, A., Koch, K., Taipale, R., Zimmer, I., Schnitzler J.-P., and Rinne, J.: Determination of de novo and pool emissions of terpenes from four common boreal/alpine trees by ${ }^{13} \mathrm{CO}_{2}$ labeling and PTR-MS analysis, Plant, Cell Environ., 33, 781-792, doi:10.1111/j.1365-3040.2009.02104.x, 2010.

Haapanala, S., Hakola, H., Hellén, H., Vestenius, M., Levula, J., and Rinne, J.: Is forest management a significant source of monoterpenes into the boreal atmosphere?, Biogeosciences, 9, 12911300, doi:10.5194/bg-9-1291-2012, 2012.

Hakola, H., Tarvainen, V., Laurila, T., Hiltunen, V., Hellén, H., and Keronen, P.: Seasonal variation of VOC concentrations above a boreal coniferous forest, Atmos. Environ., 37, 1623-1634, 2003.

Hakola, H., Hellén, H., and Laurila, T.: Ten years of light hydrocarbon $\left(\mathrm{C}_{2}-\mathrm{C}_{6}\right)$ concentration measurements in background air in Finland, Atmos. Environ., 40, 3621-3630, 2006a.

Hakola, H., Tarvainen, V., Bäck, J., Ranta, H., Bonn, B., Rinne, J., and Kulmala, M.: Seasonal variation of mono- and sesquiterpene emission rates of Scots pine, Biogeosciences, 3, 93-101, doi:10.5194/bg-3-93-2006, 2006b.

Hakola, H., Hellén, H., Tarvainen, V., Bäck, J., Patokoski, J., and Rinne, J.: Annual variations of atmospheric VOC concentrations in a boreal forest, Boreal Environ. Res., 14, 722-730, 2009.

Hari, P. and Kulmala, M.: Station for measuring ecosystematmosphere relations (SMEAR II), Boreal Environ. Res., 10, 315-322, 2005
Hellén, H., Hakola, H., Pirjola, L., Laurila, T., and Pystynen, K.H.: Ambient air concentrations, source profiles and source apportionment of 71 different $\mathrm{C}_{2}-\mathrm{C}_{10}$ volatile organic compounds at urban and residential areas in Finland, Environ. Sci. Technol., 40, 103-108, 2006.

Hellén, H., Hakola, H., Haaparanta, S., Pietarila, H., and Kauhaniemi, M.: Influence of residential wood combustion on local air quality, Sci. Total Environ., 393, 283-290, 2008.

Hellén, H., Kuronen, P., and Hakola, H.: Heated stainless steel tube for ozone removal in the ambient air measurements of mono- and sesquiterpenes, Atmos. Environ., 57, 35-40, 2012.

Helmig, D., Revermann, T., Pollmann, J., Kaltschmidt, O., Hernandez, A. J., Bocquet, F., and David, D.: Calibration system and analytical considerations for quantitative sesquiterpene measurements in air, Journal of Chromatography A, 1002, 193-211, 2003.

Hoffmann, T., Odum J. R., Bowman, F., Collins, D., Klockow, D., Flagan, R. C., and Seinfeld, J. H.: Formation of organic aerosols from the oxidation of biogenic hydrocarbons, J. Atmos. Chem., 26, 189-222, 1997.

Holzke, C., Hoffmann, T., Jaeger, L., Koppmann, R., and Zimmer, W.: Diurnal and seasonal variation of monoterpene and sesquiterpene emissions from Scots pine (Pinus sylvestris L.), Atmos. Environ., 40, 3174-3185, 2006.

Janson, R.: Monoterpene emissions from Scots pine and Norwegian spruce, J. Geophys. Res., 98, 2839-2850, 1993.

Jardine, K., Yañez Serrano, A., Arneth, A., Abrell, L., Jardine, A., van Haren, J., Artaxo, P., Rizzo, L. V., Ishida, F. Y., Karl, T., Kesselmeier, J., Saleska, S., and Huxman, T.: Within canopy sesquiterpene ozonolysis in Amazonia, J. Geophys. Res., 116, D19301, doi:10.1029/2011JD016243, 2011.

Jones, C. E., Hopkins, J. R., and Lewis, A. C.: In situ measurements of isoprene and monoterpenes within a south-east Asian tropical rainforest, Atmos. Chem. Phys., 11, 6971-6984, doi:10.5194/acp-11-6971-2011, 2011.

Kleinman, L. I.: The dependence of tropospheric ozone production rate on ozone precursors, Atmos. Environ., 39, 575-586, 2005.

Kuhn, U., Rottemberger, S., Biesenthal, T., Wolf, A., Schebeske, G., Ciccioli, P., Brancaleoni, E., Frattoni, M., Tavares, T. M., and Kesselmeier, J.: Isoprene and monoterpene emissions of Amazonian tree species during the wet season: Direct and indirect investigations on controlling environmental functions, J. Geophys. Res., 107, 8071, doi:10.1029/2001JD000978, 2002.

Kulmala, M., Toivonen, A., Mäkelä, J. M., and Laaksonen, A.: Analysis of the growth of nucleation mode particles observed in Boreal forest, Tellus B, 50, 449-462, 1998.

Kulmala, M., Kerminen, V.-M., Anttila, T., Laaksonen, A., and O'Dowd, C.: Organic aerosol formation via sulphate cluster activation, J. Geophys. Res., 109, D04205, doi:10.1029/2003JD003961, 2004a.

Kulmala, M., Suni, T., Lehtinen, K. E. J., Dal Maso, M., Boy, M., Reissell, A., Rannik, Ü., Aalto, P., Keronen, P., Hakola, H., Bäck, J., Hoffmann, T., Vesala, T., and Hari, P.: A new feedback mechanism linking forests, aerosols, and climate, Atmos. Chem. Phys., 4, 557-562, doi:10.5194/acp-4-557-2004, 2004b.

Laurila T. and Hakola, H.: Seasonal Cycle of C2-C5 hydrocarbons over the Baltic Sea and Northern Finland, Atmos. Environ., 30, 1597-1607, 1996. 
Lappalainen, H. K., Sevanto, S., Bäck, J., Ruuskanen, T. M., Kolari, P., Taipale, R., Rinne, J., Kulmala, M., and Hari, P.: Daytime concentrations of biogenic volatile organic compounds in a boreal forest canopy and their relation to environmental and biological factors, Atmos. Chem. Phys., 9, 5447-5459, doi:10.5194/acp-9-5447-2009, 2009.

Liao, L., Dal Maso, M., Taipale, R., Rinne, J., Ehn, M., Junninen, H., Äijälä, M., Nieminen, T., Alekseychik, P., Hulkkonen, M., Worsnop, D. R., Kerminen, V.-M., and Kulmala, M.: Monoterpene pollution episodes in a forest environment: indication of anthropogenic origin and association with aerosol particles, Boreal Environ. Res., 16, 288-303, 2011.

Ortega J., Helmig, D., Guenther, A., Harley, P., Pressley, S., and Vogel, C.: Flux estimates and $\mathrm{OH}$ reaction potential of reactive biogenic volatile organic compounds (BVOCs) from a mixed northern hardwood forest, Atmos. Environ., 41, 5479-5495, 2007.

Rinne, J., Hakola, H., Laurila, T., and Rannik, Ü.: Canopy scale monoterpene emissions of Pinus sylvestris dominated forests, Atmos. Environ., 34, 1099-1107, 2000.

Rinne, H. J. I., Guenther, A. B., Greenberg, J. P., and Harley, P. C.: Isoprene and monoterpene fluxes measured above Amazonian rainforest and their dependence on light and temperature, Atmos. Environ., 36, 2421-2426, 2002.

Rinne, J., Ruuskanen, T. M., Reissell, A., Taipale, R., Hakola, H., and Kulmala, M.: On-line PTR-MS measurements of atmospheric concentrations of volatile organic compounds in a European boreal forest ecosystem, Boreal Environ. Res., 10, 425-436, 2005.

Rinne, J., Bäck, J., and Hakola, H.: Biogenic volatile organic compound emissions from the Eurasian taiga: current knowledge and future directions, Boreal Environ. Res., 14, 807-826, 2009.

Ruuskanen, T. M., Kajos, M., Hellén, H., Hakola, H., Tarvainen, V., and Rinne, J.: Volatile organic compound emissions from Siberian larch, Atmos. Environ., 41, 5807-5812, 2007.

Seco, R., Peñuelas, J., Filella, I., Llusià, J., Molowny-Horas, R., Schallhart, S., Metzger, A., Müller, M., and Hansel, A.: Contrasting winter and summer VOC mixing ratios at a forest site in the Western Mediterranean Basin: the effect of local biogenic emissions, Atmos. Chem. Phys., 11, 13161-13179, doi:10.5194/acp11-13161-2011, 2011.
Shu, Y. and Atkinson, R.: Atmospheric lifetimes and fates of a series of sesquiterpenes, J. Geophys. Res., 100, 7275-7281, 1995.

Sillman, S.: The relation between ozone, $\mathrm{NO}_{x}$ and hydrocarbons in urban and polluted rural environments, Atmos. Environ., 33, 1821-1845, 1999.

Taipale, R., Kajos, M. K., Patokoski, J., Rantala, P., Ruuskanen, T. M., and Rinne, J.: Role of de novo biosynthesis in ecosystem scale monoterpene emissions from a boreal Scots pine forest, Biogeosciences, 8, 2247-2255, doi:10.5194/bg-8-22472011, 2011.

Tarvainen, V., Hakola, H., Hellén, H., Bäck, J., Hari, P., and Kulmala, M.: Temperature and light dependence of the VOC emissions of Scots pine, Atmos. Chem. Phys., 5, 989-998, doi:10.5194/acp-5-989-2005, 2005.

Tarvainen, V., Hakola, H., Rinne, J., Hellén, H., and Haapanala, S.: Towards a comprehensive emission inventory of terpenoids from boreal ecosystems, Tellus, 59B, 526-534, 2007.

Tunved, P., Hansson, H.-C., Kerminen, V.-M., Ström, J., Dal Maso, M., Lihavainen, H., Viisanen, Y., Aalto, P. P., Komppula, M., and Kulmala, M.: High natural aerosol loading over Boreal forests, Science, 312, 261-263, 2006.

Yassaa, N. and Williams, J.: Analysis of enantiomeric and nonenantiomeric monoterpenes in plant emissions using portable dynamic air sampling/solid-phase microextraction (PDASSPME) and chiral gas chromatography/mass spectrometry, Atmos. Environ., 39, 4875-4884, 2005.

Yassaa, N. and Williams, J.: Enantiomeric monoterpene emissions from natural and damaged Scots pine in a boreal coniferous forest measured using solid-phase microextraction and gas chromatography/mass spectrometry, J. Chromatogr. A., 1141, 138144, doi:10.1016/J.Chroma.2006.12.006, 2007.

Yassaa, N., Brancaleoni, E., Frattoni, M., and Ciccioli, P.: Trace level determination of enantiomeric monoterpenes in terrestrial plant emission and in the atmosphere using a $\beta$-cyclodextrin capillary column coupled with thermal desorption and mass spectrometry, J. Chromatogr. A, 915, 185-197, 2001.

Williams, J., Yassaa, N., Bartenbach, S., and Lelieveld, J.: Mirror image hydrocarbons from Tropical and Boreal forests, Atmos. Chem. Phys., 7, 973-980, doi:10.5194/acp-7-973-2007, 2007. 